\title{
Identification of Nicotiana benthamiana Genes Involved in Pathogen-Associated Molecular Pattern-Triggered Immunity
}

\author{
Suma Chakravarthy, ${ }^{1}$ André C. Velásquez, ${ }^{1,2}$ Sophia K. Ekengren, ${ }^{3}$ Alan Collmer, ${ }^{2}$ and Gregory B. Martin ${ }^{1}$ \\ ${ }^{1}$ Boyce Thompson Institute for Plant Research, Ithaca, NY 14853-1801, U.S.A.; ${ }^{2}$ Department of Plant Pathology \\ and Plant-Microbe Biology, Cornell University, Ithaca, NY 14853, U.S.A.; ${ }^{3}$ Department of Botany, Stockholm University, \\ S-106 91 Stockholm, Sweden
}

Submitted 4 September 2009. Accepted 1 February 2010.

In order to identify components of pathogen-associated molecular pattern-triggered immunity (PTI) pathways in Nicotiana benthamiana, we conducted a large-scale forward-genetics screen using virus-induced gene silencing and a cell-death-based assay for assessing PTI. The assay relied on four combinations of PTI-inducing nonpathogens and cell-death-causing challenger pathogens and was first validated in plants silenced for $F L S 2$ or $B A K 1$. Over 3,200 genes were screened and 14 genes were identified that, when silenced, compromised PTI as judged by the celldeath-based assay. Further analysis indicated that the 14 genes were not involved in a general cell death response. A subset of the genes was found to act downstream of FLS2mediated PTI induction, and silencing of three genes compromised production of reactive oxygen species in leaves exposed to flg22. The 14 genes encode proteins with potential functions in defense and hormone signaling, protein stability and degradation, energy and secondary metabolism, and cell wall biosynthesis and provide a new resource to explore the molecular basis for the involvement of these processes in PTI.

Plants are constantly threatened by disease-causing organisms in their environment. To protect themselves, plants have evolved elaborate inducible mechanisms to prevent or slow down pathogen infection. The first line of inducible plant defense involves the detection of slowly evolving epitopes present in molecules that are of key importance to a pathogen's lifestyle. These epitopes are referred to as microbial-associated molecular patterns or pathogen-associated molecular patterns (MAMPs or PAMPs)

S. Chakravarthy and A. C. Velásquez contributed equally to this work and are considered co-first authors.

Nucleotide sequence data for the gene fragments used for VIGS are available in the GenBank database under the following accession numbers: GW691608 (aldehyde dehydrogenase); GW691620 (alternative oxidase); GW691615 (anionic peroxidase); GW691609 (cathepsin B); GW691616 (cinnamic acid 4-hydroxylase); GW691610 (cyclophilin); GW691611 (cytochrome C); GW691612 (Drm-3); GW691613 ( $N$-hydroxycinnamoyl/benzoyltransferase); GW691614 (plastocyanin); GW691617 (proteasome 26S ATPase subunit 1 variant); GW691618 (transducin); GW691619 (ubiquitinactivating enzyme).

Corresponding author: G. B. Martin; Telephone: +1.607.254.1208; Fax: +1.607.255.6695; E-mail: gbm7@ cornell.edu

* The $\boldsymbol{e}$-Xtra logo stands for "electronic extra" and indicates that six supplementary tables and one supplementary figure are available online. and are present not only in pathogens but also in diverse microbes. PAMPs are recognized by pattern recognition receptors (PRR) and this perception triggers PAMP-triggered immunity (PTI), which effectively prevents colonization of plant tissues by potential pathogens (Bent and Mackey 2007). Successful bacterial pathogens deploy effectors that suppress PTI and cause disease and, in turn, some plants have evolved resistance $(R)$ genes that recognize the activity of effectors, which leads to effector-triggered immunity (ETI) (Bent and Mackey 2007).

Bacterial PAMPs include flagellin, cold-shock protein (CSP), elongation factor $\mathrm{Tu}$ (EF-Tu), and peptidoglycan (PGN) (Boller and Felix 2009). The two best-characterized plant PRR are from Arabidopsis and both recognize bacterial PAMPs: FLS2 detects a 22-amino-acid epitope (flg22) in flagellin and EFR detects an 18-amino-acid epitope (elf18) in EFTu (Chinchilla et al. 2006; Zipfel et al. 2006). Both of these proteins are leucine-rich repeat receptor-like kinases (LRRRLK) and FLS2, in particular, has been studied intensively. FLS2 directly binds the flg22 peptide after which it associates with the BRI1-associated kinase (BAK1) (Chinchilla et al. 2007; Heese et al. 2007). Plants with disrupted expression of the FLS2 or BAK1 genes are compromised for PTI and more susceptible to certain bacterial pathogens (Zipfel et al. 2004; Heese et al. 2007). In addition to FLS2 and EFR, there are several less well-characterized PRR in plants (Ron and Avni 2004; Miya et al. 2007; Gimenez-Ibanez et al. 2009)

Activation of a PRR by its cognate PAMP leads to a variety of rapid responses, including an oxidative burst, an intracellular increase in calcium concentration, cell wall callose deposition, mitogen-activated protein kinase (MAPK) activation, phytoalexin production, and a complex transcriptional response (Schwessinger and Zipfel 2008). PTI-induced transcriptional responses include upregulation of a large number of genes, including many that encode RLK, some of which may be involved in PAMP perception, and of transcription factors which could be involved in amplifying the PTI response (Navarro et al. 2004; Thilmony et al. 2006). Interestingly, many of the genes induced by EF-Tu or PGN are similar to flg22-induced genes (Zipfel et al. 2006; Gust et al. 2007), suggesting that there is significant overlap among the responses to different PAMPs.

Different genetic and molecular approaches have been used to dissect signaling pathways in PTI, yet relatively little is known about PRR or the processes that these host receptors activate in plants during the PTI response (Zipfel 2009). Two recent reports used large-scale genetic screens to identify components of the elf18-induced signaling pathway in Arabidopsis 
A

(i)

(ii)

(iii)

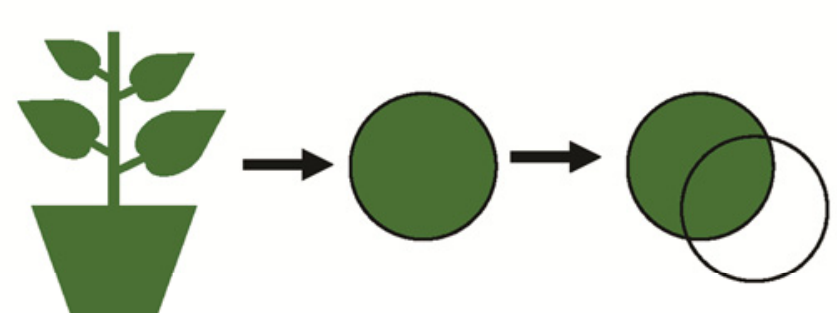

Induction Challenge (iv)

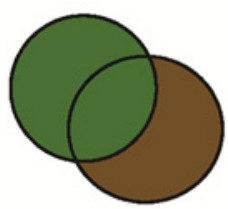

(v)

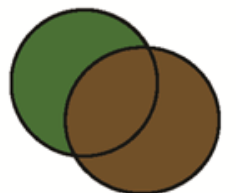

Outcomes

B

Hypersensitive Response

Disease

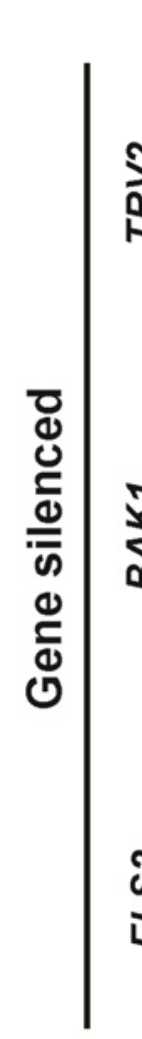

\section{P. fluorescens I DC3000 \\ P. putida I \\ DC3000}

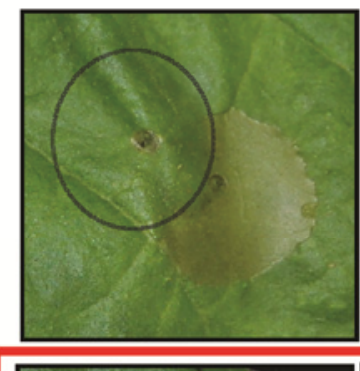

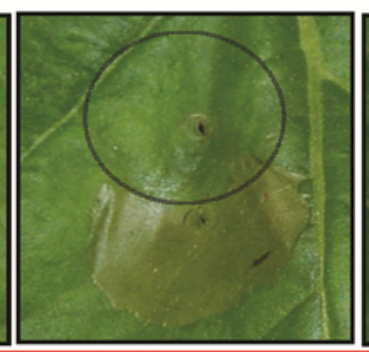

\section{P. fluorescens I DCAhopQ1-1}
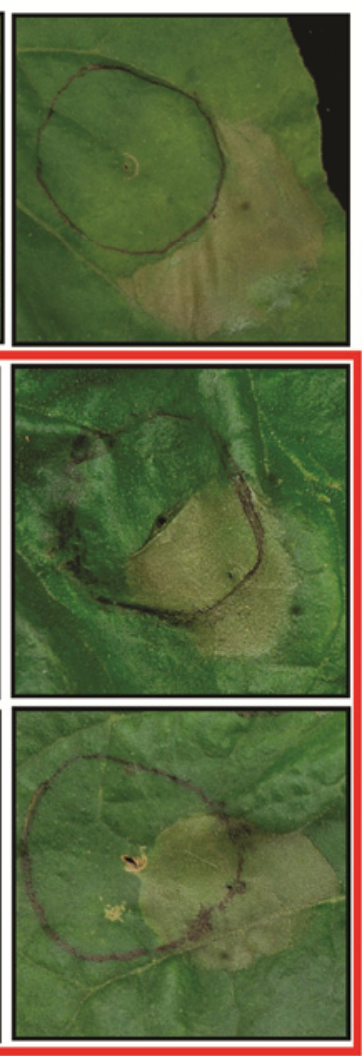

A. tumefaciens I P. s. pv. tabaci
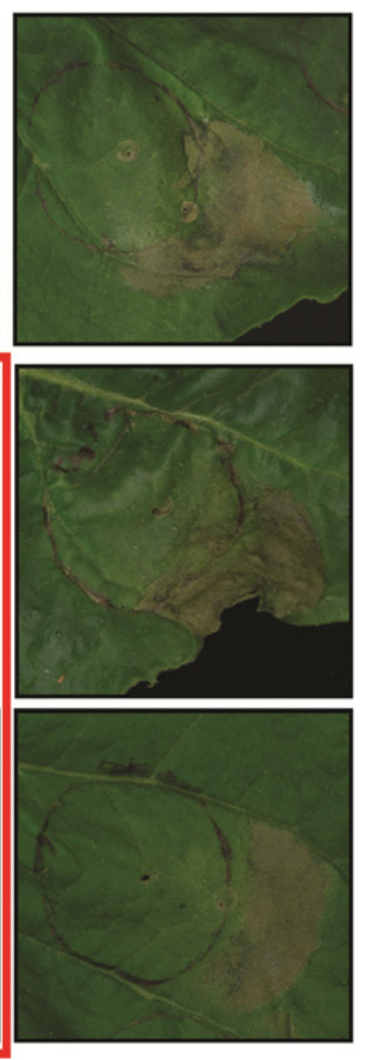

Fig. 1. Assay for pathogen-associated molecular pattern-triggered immunity (PTI). A, Diagram depicting the cell-death-based assay to determine the involvement of a particular gene in PTI. (i) Virus-induced gene silencing (VIGS) of the candidate gene. (ii) Four weeks after initiating VIGS, PTI is induced in silenced plants by infiltration of a nonpathogen onto leaves. (iii) A partially overlapping area is challenged with a hypersensitive response (HR) or diseasecausing strain $7 \mathrm{~h}$ after PTI induction. Cell death typically appears 2 to 5 days later in the challenged area. This assay has two possible outcomes: (iv) lack of cell death in the overlapping area due to induction of PTI or (v) Cell death in the overlapping area due to compromised PTI. B, PTI assay using the four different combinations of PTI inducers and cell death-causing challengers on nonsilenced TRV2 control plants and FLS2-or BAK1-silenced plants. Photographs were taken 2 days after inoculation of the HR-causing strain (Pseudomonas syringae pv. tomato DC3000 or DC) and 4 to 5 days after inoculation of the disease-causing strains (DCAhopQ1-1 and P. syringae pv. tabaci). The red box indicates those combinations of inducers and challengers in which PTI was compromised, as observed by the occurrence of cell death in the overlapping area of inoculation. The photographs for the HR challenge infiltrations are from a single experiment, and those for the disease challenge infiltrations are from a separate experiment. The area of infiltration of PTI inducers is circled in black either digitally or with a marker. 
(Li et al. 2009; Saijo et al. 2009). The studies involved screening of 137,500 or $>60,000$ EMS-mutagenized lines and identified genes involved in ER quality control (ER-QC) that were responsible for the proper biogenesis of EFR.

Virus-induced gene silencing (VIGS) is a powerful method that has been used to identify genes involved in plant defense responses. A gene that acts as a regulator of immunity-associated cell death and genes involved in $R$ gene signaling or stabilization were identified during large-scale VIGS screens ( $\mathrm{Lu}$ et al. 2003; del Pozo et al. 2004; Peart et al. 2005). Genomewide RNA interference (RNAi) screens also have been used to discover components of the animal innate immune response (Foley and O'Farrell 2004; Alper et al. 2008; Cronin et al. 2009).

In order to identify genes involved in PTI, we conducted a VIGS-based screen in Nicotiana benthamiana, a species being increasingly used as a model to study plant-microbe interactions (Goodin et al. 2008). Knowledge gained from this species is also potentially transferable to closely related solanaceous species such as tomato, potato, and pepper. To efficiently assay for PTI in leaves of $N$. benthamiana, we relied on a previously developed cell-death-based assay (Oh and Collmer 2005). In this assay, a nonpathogen is first infiltrated into leaves in order to induce PTI. Several hours later, a "challenger" inoculation is performed in a partially overlapping area with a cell-deathcausing bacterium. Cell death caused by the challenger may be the result of either the hypersensitive response (HR) or disease caused by pathogenic bacteria. In the leaf area in which PTI has been induced by inoculation of the nonpathogen, challenger cell death is delayed or does not occur (Klement et al. 2003; Oh and Collmer 2005). Conversely, appearance of cell death in the overlapping area of inoculation indicates a breakdown of PTI. The lack of cell death in the overlapping area is likely the result of impaired delivery of effectors, as indicated by the reduced delivery by Pseudomonas syringae pv. tomato DC3000 challenger inoculum of the AvrPto-Cya translocation reporter into PTI-induced tissue (Oh et al. 2010). This method has the advantage that it measures overall plant response to live bacteria instead of that to individual PAMPs.

In this study, we report the screening of over 3,200 genes by a combined approach of VIGS and the PTI cell-death-based assay. Fourteen genes were identified that appear to act in pathways involved in defense and hormone signaling, protein stability and degradation, energy and secondary metabolism, or cell wall biosynthesis. This collection of genes provides a resource to further investigate the molecular basis for the involvement of each of these processes in PTI.

\section{RESULTS}

A cell-death-based assay for PTI is validated

in plants silenced for $F L S 2$ or $B A K 1$.

We initially optimized the cell-death-based assay for PTI by evaluating 18 different combinations of inducers and challengers (Fig. 1A; Supplementary Table S1). The combinations tested varied in their effectiveness of inducing PTI, as seen by the occurrence or lack of cell death in the overlapping area of inoculation. This suggested that differences exist in the nature of PTI induced by different bacteria, as well as in the ability of the challengers to overcome the PTI response. Four combinations of inducers and challengers were ultimately chosen based on their ability to consistently show inhibition of cell death in the overlapping area of inoculation in wild-type $N$. benthamiana plants (Table 1).

These four inducer-challenger combinations were tested on plants silenced for $F L S 2$ or $B A K 1$, genes which have been shown to act as important components of PTI in $N$. benthamiana (Hann and Rathjen 2007; Heese et al. 2007). Cell death was observed in the overlapping area of inoculation with three of the four inducer-challenger combinations tested on FLS2- or BAK1-

\section{Hypersensitive Response}

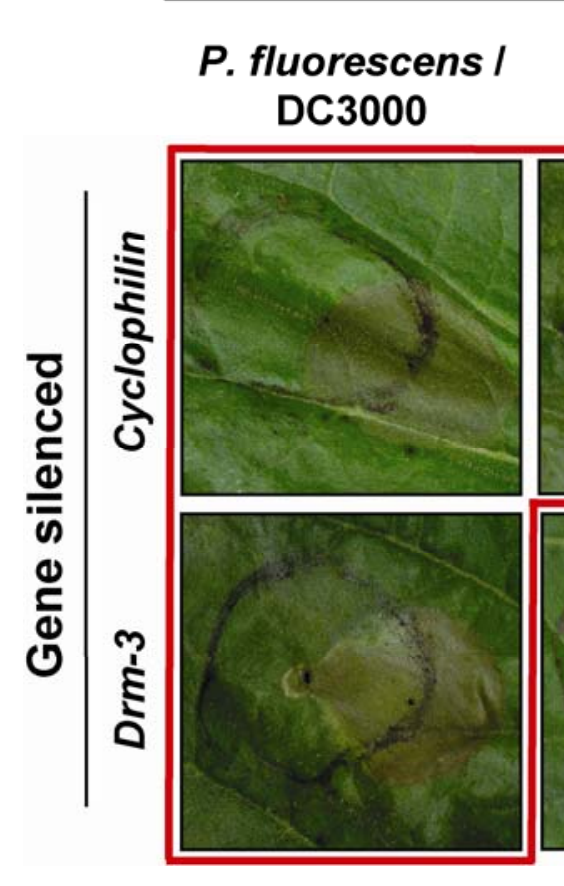

P. putida I DC3000

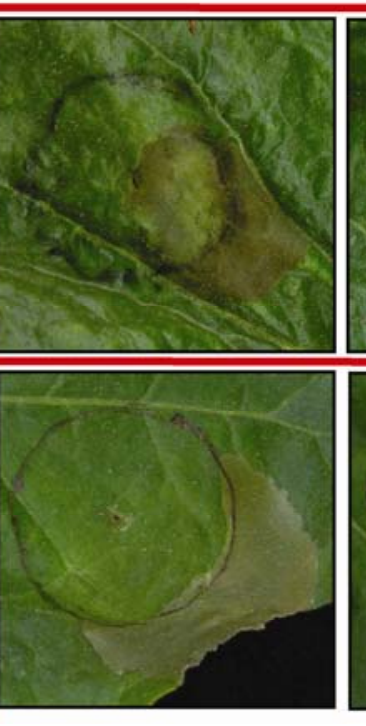

P. fluorescens I DC $\Delta$ hopQ1-1

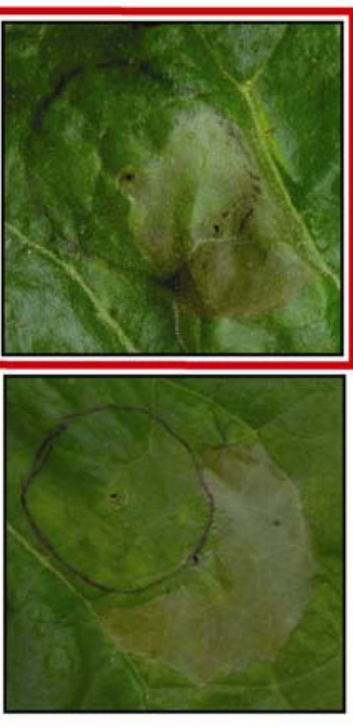

A. tumefaciens I P. s. pv. tabaci

Fig. 2. Cell-death-based assay for two candidate genes identified from the virus-induced gene silencing library screen. Cyclophilin- and Drm3-silenced plants were photographed 2 days after inoculation of the hypersensitive response-causing strain (Pseudomonas syringae pv. tomato DC 3000 ) and 4 to 5 days after inoculation of the disease-causing strains (DCAhopQ1-1 and $P$. syringae pv. tabaci). The red box indicates those combinations of inducers and challengers in which pathogen-associated molecular pattern-triggered immunity was compromised, as observed by the occurrence of cell death in the overlapping area of inoculation. 
silenced plants (Fig. 1B). This indicated a compromised PTI response in the plants silenced for $F L S 2$ or $B A K 1$ and validated the cell-death-based assay. These results also suggest that flagellin is one of the most important PAMPs of $P$. fluorescens and $P$. putida recognized by $N$. benthamiana because silencing of FLS2 was able to attenuate the PTI response despite the presumed presence of other PAMPs in these bacteria.

\section{Screening of a VIGS library identifies seven genes as playing a role in PTI.}

We silenced 3,072 genes from a previously constructed VIGS library derived from leaf tissues exposed to various biotic and abiotic elicitors ( $N$. benthamiana mixed-elicitor cDNA [cNbME]) (del Pozo et al. 2004). The elicitors used were Agrobacterium tumefaciens, $P$. syringae pv. tabaci, $P$. syringae pv. tomato, salicylic acid (SA), jasmonic acid, and ethylene. The cell death assay was performed on gene-silenced plants using the four different inducer-challenger combinations. FLS2-silenced and $B A K 1$-silenced plants were included as controls in every experiment, and cell death in the overlapping inducer-challenger leaf area was observed up to $75 \%$ of the time for these two genes, depending on the inducer-challenger combination (Table 2). Seven genes, representing just $0.23 \%$ of the 3,072 genes screened, were ultimately identified as compromising PTI when silenced (Table 2; Fig. 2; Supplementary Fig. S1). Each of these seven genes was silenced a minimum of 15 additional times and tested with each of the four inducer-challenger combinations (Table 2). These followup experiments were evaluated for each of the seven genes with a Fisher's exact test $(\alpha=0.05)$, which revealed that PTI was compromised for at least one of the inducer-challenger combinations (Table 2). The genes that were identified from this screen encode proteins with putative functions in protein stability and degradation, hormone signaling, and secondary metabolism (Supplementary Table S2).

We next performed bacterial growth assays with plants silenced for each of the seven genes. Gene-silenced plants were syringe inoculated with the nonpathogen P. fluorescens or an attenuated pathogenic strain of $P$. syringae pv. tomato DC3000 lacking the effectors avrPto, avrPtoB, and hopQ1-1 (Kvitko et al. 2009). Growth assays with the DC3000 triple mutant were performed with or without preinduction of PTI with $P$. fluorescens. We also dip-inoculated silenced plants with $P$. syringae pv. tabaci or $P$. syringae pv. syringae B728a. No changes in bacterial growth were detected in any of the gene-silenced plants compared with TRV-only infected plants. These results may suggest that the cell-death-based assay is more sensitive than bacterial population assays in detecting subtle defects in PTI responses. Specifically, the higher inoculum level of the challenger in the cell death assay compared with that used in a standard bacterial growth assay may allow better detection of a breakdown in PTI.

\section{The plastocyanin gene is induced during the PTI response.}

The expression of a large number of genes is induced during the PTI response in plants (Navarro et al. 2004; Zipfel et al. 2004). Some of these genes (for example, those encoding the PRR FLS2 and EFR) have established roles in PTI (Chinchilla et al. 2006; Zipfel et al. 2006). To examine whether PTI causes increased expression of any of the seven genes identified from our library screen, we performed reverse-transcription polymerase chain reaction (RT-PCR) on RNA isolated from $N$. benthamiana leaves that had been infiltrated with either the nonpathogen $P$. fluorescens or $10 \mathrm{mM} \mathrm{MgCl}_{2}$ (Fig. 3). Transcript abundance of FLS2 was increased at 6 and $12 \mathrm{~h}$ after $P$. fluorescens infiltration compared with the $\mathrm{MgCl}_{2}$ treatment (Fig. 3) and returned to control levels $24 \mathrm{~h}$ after treatment (not shown). Of the seven genes tested, only the plastocyanin gene showed increased transcript abundance, visible at 12 and $24 \mathrm{~h}$ after $P$. fluorescens infiltration compared with the $\mathrm{MgCl}_{2}$ control.

\section{Screening of a collection of immunity-induced genes identifies seven as playing a role in PTI.}

The result with the plastocyanin gene indicated that at least some genes whose silencing compromises PTI are

Table 1. Combinations of pathogen-associated molecular pattern-triggered immunity (PTI)-inducing and hypersensitive response (HR)- or disease-causing challenge microbes used in the assays

\begin{tabular}{|c|c|c|c|}
\hline Inducer & Challenger & Combination & Outcome $^{\mathrm{a}}$ \\
\hline Pseudomonas fluorescens 55 & P. syringae pv. tomato DC3000 & $\mathrm{Pf} / \mathrm{DC}$ & HR \\
\hline P. putida $\mathrm{KT} 2440$ & P. syringae pv. tomato $\mathrm{DC} 3000$ & $\mathrm{Pp} / \mathrm{DC}$ & HR \\
\hline P. fluorescens 55 & P. syringae pv. tomato DC3000 $\Delta h o p Q 1-1$ & Pf/Q1-1 & Disease \\
\hline Agrobacterium tumefaciens GV2260 & P. syringae pv. tabaci 11528 & Agro/Ptab & Disease \\
\hline
\end{tabular}

${ }^{\text {a }}$ Expected outcome in the overlapping infiltration area if PTI resulting from the inducer is compromised by silencing of a particular gene.

Table 2. Percentage of plants in which pathogen-associated molecular pattern-triggered immunity (PTI) was compromised when candidate genes from the Nicotiana benthamiana mixed-elicitor cDNA virus-induced gene silencing library were silenced and evaluated using the cell-death-based assay ${ }^{\mathrm{a}}$

\begin{tabular}{|c|c|c|c|c|c|}
\hline \multirow[b]{2}{*}{ Gene silenced } & \multirow[b]{2}{*}{ Category } & \multicolumn{4}{|c|}{ Plants with PTI compromised (\%) } \\
\hline & & Pf/DC & Pp/DC & Pf/Q1-1 & Agro/Ptab \\
\hline TRV2 & $\ldots$ & 0 & 0 & 0 & 0 \\
\hline$B A K 1$ & Signaling & 53 & 22 & 44 & 3 \\
\hline$F L S 2$ & PRR & 75 & 48 & 66 & 5 \\
\hline$A L D H$ & Secondary metabolism & 8 & 4 & 21 & 8 \\
\hline Cathepsin B & Protease & 17 & 17 & 33 & 8 \\
\hline Cyclophilin & Protein folding & 33 & 26 & 44 & 4 \\
\hline Cytochrome C & Secondary metabolism & 32 & 8 & 32 & 4 \\
\hline Drm-3 & Hormone signaling & 45 & 11 & 17 & 6 \\
\hline$H C B T$ & Secondary metabolism & 20 & 24 & 16 & 8 \\
\hline Plastocyanin & Secondary metabolism & 29 & 13 & 38 & 13 \\
\hline
\end{tabular}

${ }^{a}$ A minimum of 16 plants was evaluated for each assay. Percentages in bold represent those combinations in which PTI was compromised as determined by pairwise comparisons of the TRV2 control with each of the candidate genes with a Fisher's exact test $(\alpha=0.05)$. Abbreviations: $P f=P$ seudomonas fluorescens, $\mathrm{DC}=$ P. syringae pv. tomato $\mathrm{DC} 3000, \mathrm{Pp}=P$. putida, $\mathrm{Q} 1-1=$ P. syringae pv. tomato $\mathrm{DC} 3000 \Delta$ hopQ1-1, Agro $=$ Agrobacterium tumefaciens, $\mathrm{Ptab}=P$. syringae pv. tabaci, $\mathrm{PRR}=$ pattern recognition receptor, $\mathrm{ALDH}=$ aldehyde dehydrogenase, and $H C B T=$ anthranilate $N$-hydroxycinnamoyl/benzoyltransferase . 
upregulated by PAMPs. Therefore, as a second approach to identify genes involved in PTI, we took advantage of a previous transcriptional profiling study that had identified $>400$ genes from tomato whose expression was increased during both PTI and ETI responses to $P$. syringae pv. tomato (Mysore et al. 2002). We focused on a subset of these genes that was implicated as being induced by PAMPs and, in addition, a few genes with known roles in defense signaling, such as EDS1, SGT1, RAR1, and NPR1 (Supplementary Table S3). A fragment from each of these 133 genes was cloned into the TRV2 vector and gene silencing and subsequent cell death assays were performed as described above for the cNbME VIGS library. From this screen, seven genes representing $5.2 \%$ of the set were ultimately found to compromise PTI as judged by replicated experiments and Fisher's exact test $(\alpha=$ 0.05 ) (Table 3 ). The identified genes encode proteins with putative functions in defense signaling, energy metabolism, protein stability, secondary metabolism, and cell wall lignification.

\section{Plants silenced for four genes display morphological alterations.}

Of the 14 genes identified from the screens, 4 caused morphological alterations in plants upon silencing (Fig. 4). Plants silenced for the cyclophilin gene showed slightly curved and elongated leaf morphology, whereas cytochrome $C$-silenced plants were mildly chlorotic. Silencing of anionic peroxidase or ubiquitin-activating enzyme genes resulted in abnormal leaf morphologies and dwarf stature. None of the remaining 10 genes identified in the screen caused abnormal morphology when silenced. BAKl-silenced plants had a dwarf stature and crinkled leaves (Fig. 4), as has been reported earlier in Arabidopsis and N. benthamiana (Chinchilla et al. 2007; Heese et al. 2007).
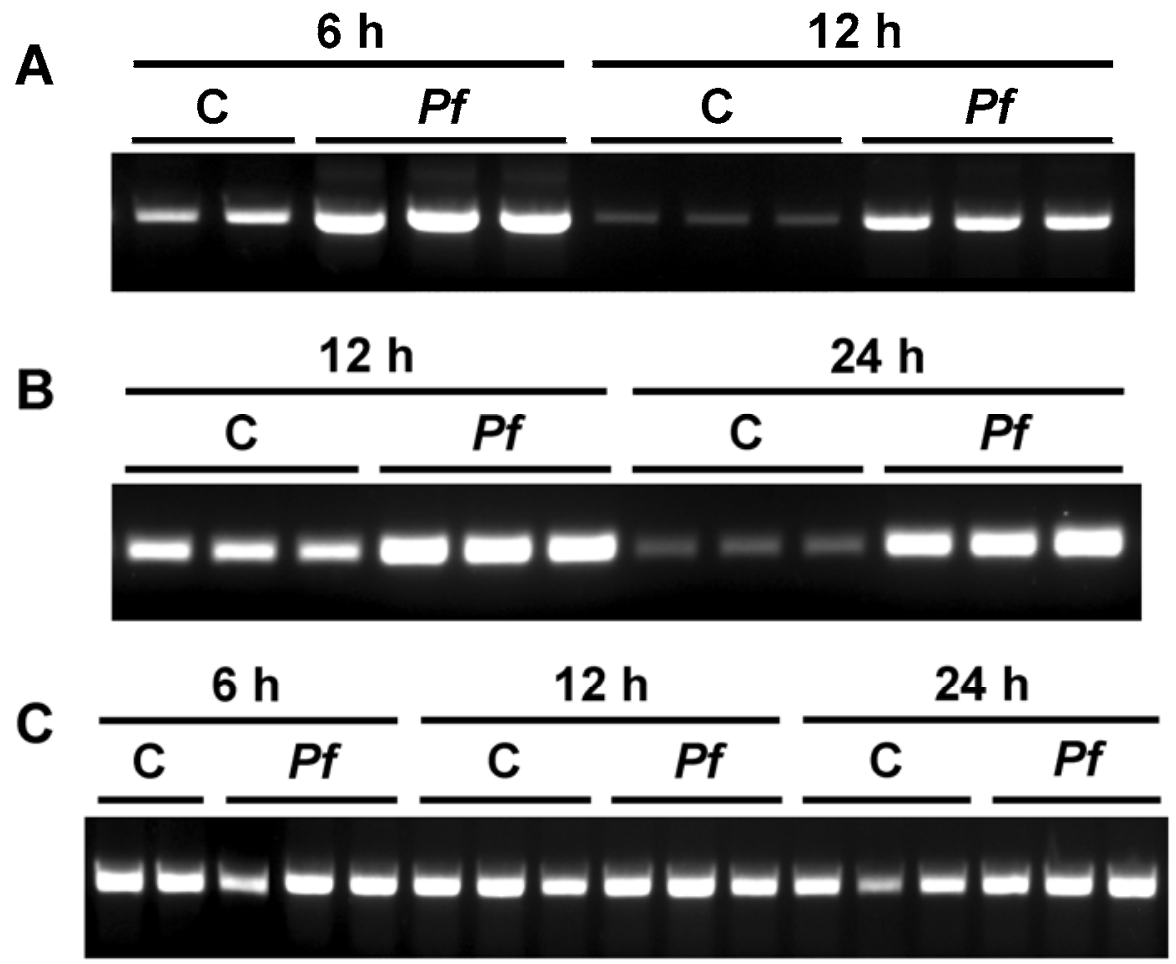

Fig. 3. Gene predicted to encode a plastocyanin is induced by pathogen-associated molecular patterns (PAMPs). Nicotiana benthamiana leaves were infiltrated with either the nonpathogen Pseudomonas fluorescens $(P f)\left(1 \times 10^{9} \mathrm{CFU} / \mathrm{ml}\right)$ as a source of PAMPs or with $10 \mathrm{mM} \mathrm{MgCl} 2$ as a control $(\mathrm{C})$. RNA was isolated from tissues at 6,12 , and $24 \mathrm{~h}$ after inoculation and transcript abundance was examined by reverse-transcription polymerase chain reaction. Only the time points at which transcript abundances were increased relative to the control are shown. Each of the three lanes within each treatment-time point corresponds to a different plant. A, FLS2; B, the plastocyanin gene; and $\mathbf{C}$, elongation factor $1 \alpha$ (control for similar abundance of RNA in each lane).

Table 3. Percentage of plants in which pathogen-associated molecular pattern-triggered immunity (PTI) was compromised when candidate genes from the immunity-induced gene collection were silenced and evaluated using the cell-death-based assay ${ }^{\mathrm{a}}$

\begin{tabular}{|c|c|c|c|c|c|}
\hline \multirow[b]{2}{*}{ Gene silenced } & \multirow[b]{2}{*}{ Category } & \multicolumn{4}{|c|}{ Plants with PTI compromised (\%) } \\
\hline & & Pf/DC & Pp/DC & Pf/Q1-1 & Agro/Ptab \\
\hline$T R V 2$ & & 0 & 0 & 0 & 0 \\
\hline Alternative oxidase & Energy metabolism & 20 & 13 & 40 & 7 \\
\hline Anionic peroxidase & Cell wall protein & 42 & 47 & 47 & 5 \\
\hline $\mathrm{CA} 4 \mathrm{H}$ & Secondary metabolism & 43 & 21 & 50 & 29 \\
\hline EDS1 & Defense signaling & 27 & 40 & 27 & 7 \\
\hline Proteasome $26 S$ subunit & Protein stability & 36 & 27 & 0 & 9 \\
\hline Transducin & Signaling & 8 & 8 & 15 & 46 \\
\hline Ubiquitin activating enzyme & Protein stability & 12 & 18 & 29 & 25 \\
\hline
\end{tabular}

a A minimum of 11 plants was evaluated for each assay. Percentages in bold represent those combinations in which PTI was compromised as determined by pairwise comparisons of the TRV2 control with each of the candidate genes with a Fisher's exact test $(\alpha=0.05)$. Abbreviations: Pf $=$ Pseudomonas fluorescens, $\mathrm{DC}=$ P. syringae pv. tomato $\mathrm{DC} 3000, \mathrm{Pp}=$ P. putida, Q1-1 = P. syringae pv. tomato DC3000 $\Delta$ hopQ1-1, Agro = Agrobacterium tumefaciens, $\mathrm{Ptab}=P$. syringae pv. tabaci, and $\mathrm{CA} 4 \mathrm{H}=$ cinnamic acid 4-hydroxylase. 
Plants silenced for aldehyde dehydrogenase, anthranilate $N$-hydroxycinnamoyl/benzoyltransferase, or ubiquitin-activating enzyme show reduced production of flg22-induced reactive oxygen species.

One of the early responses during the activation of PTI is the production of reactive oxygen species (ROS) (Boller and Felix 2009). In order to determine whether any of the identified candidate genes plays a role in PTI-associated ROS production, we measured flg22-induced ROS in plants silenced for each of the 14 genes. Plants silenced for aldehyde dehydrogenase, anthranilate $N$-hydroxycinnamoyl/benzoyltransferase (HCBT), or ubiquitin-activating enzyme showed statistically significantly lower levels of ROS production compared with nonsilenced plants (Fig. 5). None of the other 11 genes showed this reduction, and results with 2 of these are also shown in Figure 5. Plants silenced for FLS2 predictably showed drastically reduced ROS levels in these experiments.
Silencing of the PTI candidate genes does not enhance a general cell death response to the challenger inoculations.

It was possible that some of the genes we identified act as negative regulators of plant cell death. If that were the case, their silencing might lead to faster or stronger cell death in response to the challenger inoculation and be misinterpreted as being due to a breakdown of PTI in our assay. In order to examine this possibility, we infiltrated the challengers $P$. syringae pv. tomato DC3000 or P. syringae pv. tomato DC3000 $\triangle$ hop $Q 1-1$ at three different concentrations each into $N$. benthamiana leaves that were silenced for a subset of the candidate genes derived from the screen (discussed below). We did not include $P$. syringae pv. tabaci 11528 because no breakdown of PTI for these seven genes was observed for the Agrobacterium- $P$. syringae pv. tabaci combination in the cell-death-based assay. For this and subsequent experiments described in this article, we focused on the seven genes derived from the VIGS library.
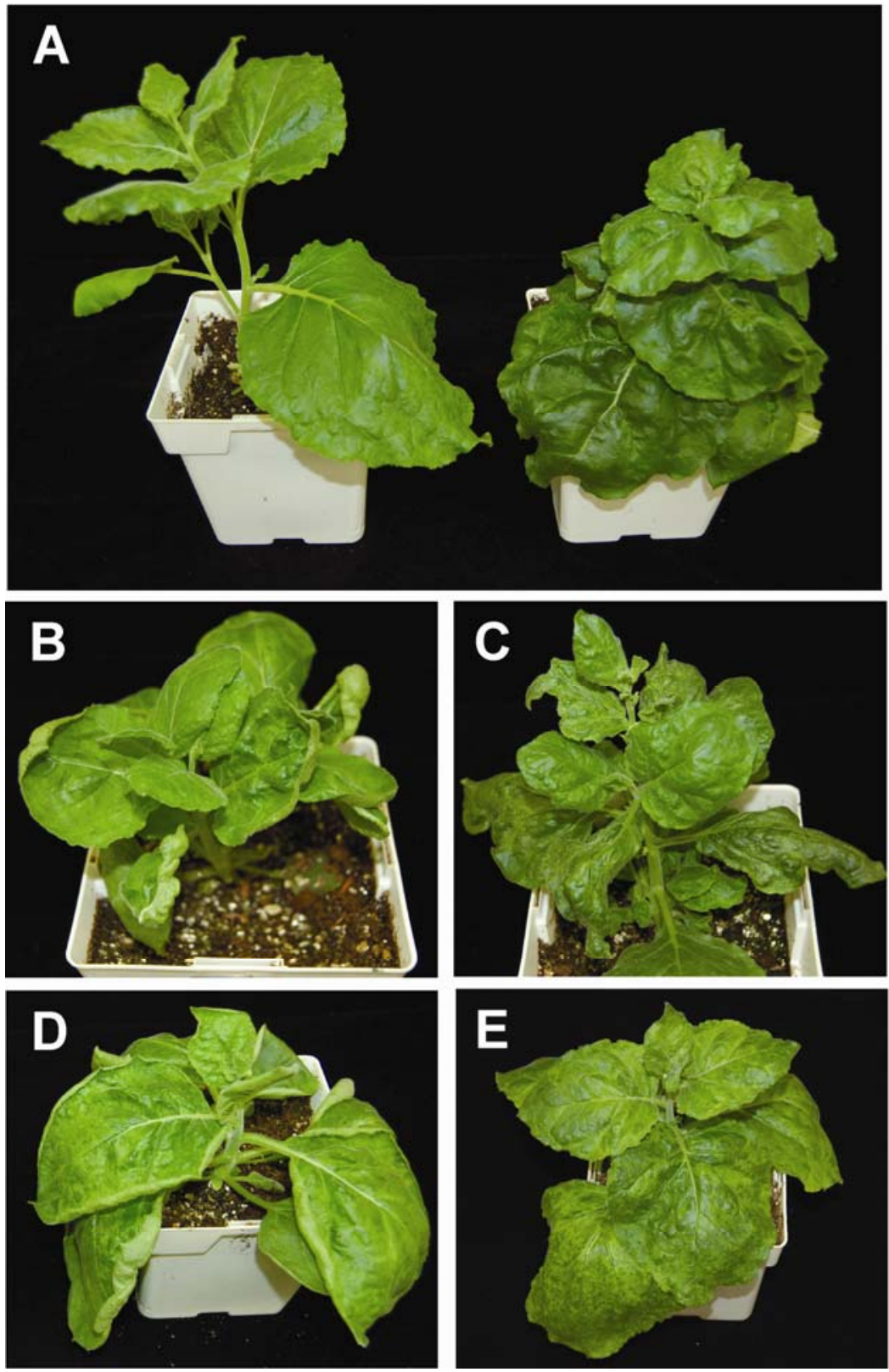

Fig. 4. Morphological alterations of plants silenced for pathogen-associated molecular pattern-triggered immunity-associated genes. A, Control TRV2 (left) and BAK1-silenced (right) plants. Plants silenced with a cDNA fragment from genes encoding the following: $\mathbf{B}$, anionic peroxidase; $\mathbf{C}$, ubiquitin activating enzyme; D, cyclophilin; and E, cytochrome $C$. Photographs were taken 4 weeks after virus-induced gene silencing was initiated. 
The progression of cell death in response to the challengers was monitored in the leaves and compared with nonsilenced TRV-only control plants (Table 4; data not shown). A Fisher's exact test $(\alpha=0.05)$ was used to determine that none of the genes showed significantly faster cell death than TRV-only control plants. $B A K 1$-silenced plants were the only exception, because they showed faster cell death than control plants in response to $P$. syringae pv. tomato DC3000 $\Delta$ hopQ1-1 (Table 4). These results indicate that the phenotypes we observed in our assays were due to compromised PTI upon gene silencing and not to a general promotion of the cell death response.

Interestingly, cell death in response to some bacterial concentrations actually developed at a slower rate in plants silenced for certain genes. This occurred, for example, in plants silenced for cathepsin B, Drm-3, HCBT, and plastocyanin at some $P$. syringae pv. tomato DC3000 or DC3000 $\Delta$ hopQ1-1 titers that were tested (Table 4; data not shown). It is possible that these genes are also involved in host pathways that are involved in cell death associated with ETI or disease. This is consistent with earlier indications that host responses during PTI, ETI, and disease may share some components but differ in timing and amplitude (Boller and Felix 2009).

\section{flg22-Induced responses are compromised in plants silenced \\ for aldehyde dehydrogenase, cyclophilin, or HCBT.}

In order to determine whether any of the candidate genes is involved specifically in FLS2-dependent responses other than ROS production, we performed the cell-death-based assay using flg22 as the inducer and $P$. syringae pv. tomato DC3000 as the challenger in plants silenced for the seven genes derived from the VIGS library screen. A compromised PTI phenotype was seen in plants silenced for genes encoding aldehyde dehydrogenase, cyclophilin, or HCBT (Table 5), suggesting that these three genes act downstream of flg22 perception and are involved in the FLS2-mediated PTI pathway. Note that both aldehyde dehydrogenase and $H C B T$ were also observed to be involved in flg22-induced ROS production (Fig. 5). Cyclophilin may play a role in PTI downstream from or independent of flg22-mediated ROS production.

\section{DISCUSSION}

We have identified 14 genes that function in diverse cellular processes in order to promote host PTI. A summary of their

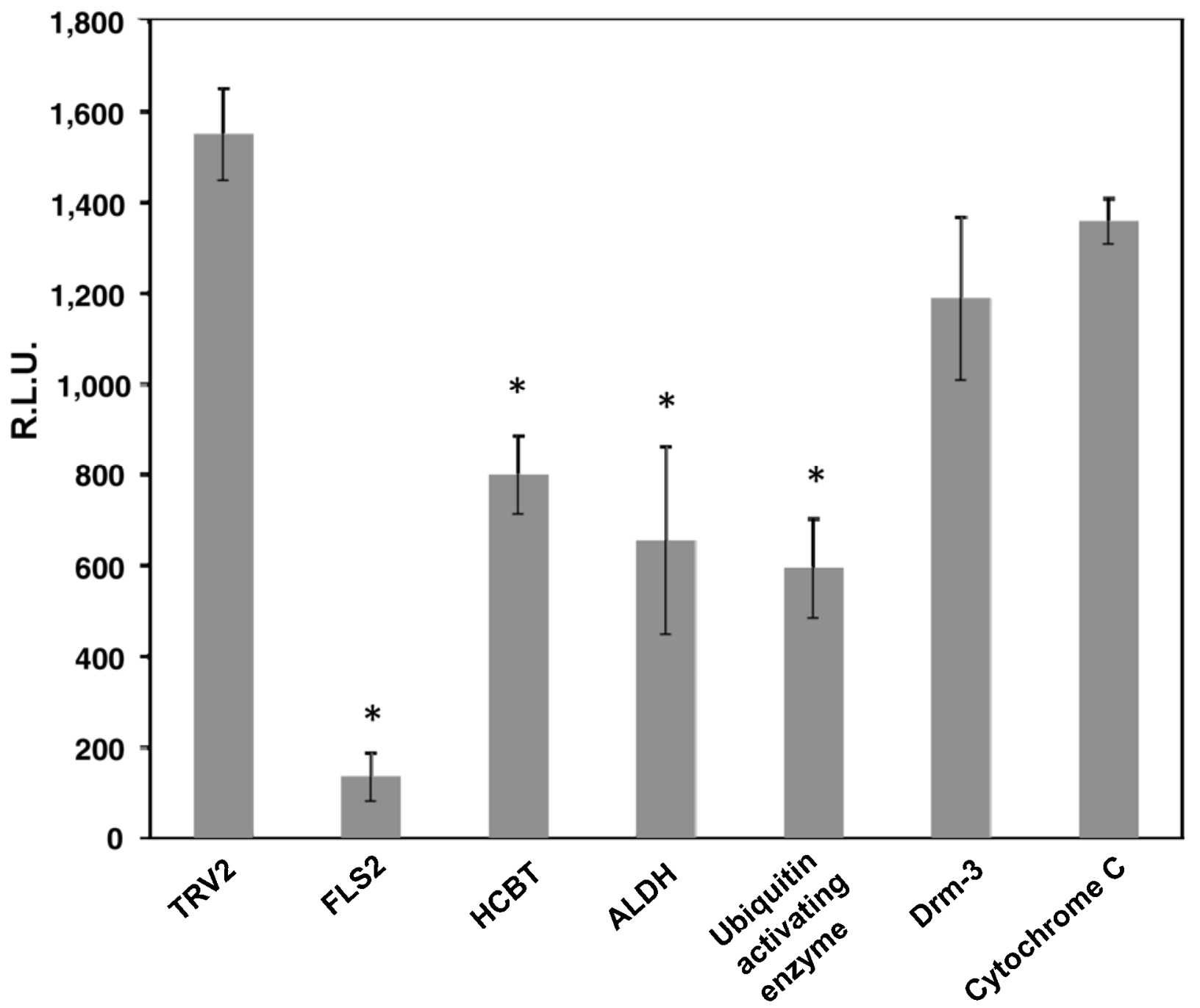

Fig. 5. Production of flg22-induced reactive oxygen species (ROS) in plants silenced for some of the genes identified from the screen. Leaf disks from silenced plants were treated with $100 \mathrm{nM}$ flg22 and ROS production was measured. The level of ROS at 20 min postinduction is shown as relative light units (R.L.U.), and the names of the genes silenced are indicated. Nonsilenced TRV2 plants served as the control. At least three silenced plants were tested for each gene, and the average R.L.U. with standard error is shown. The experiment was repeated twice with similar results. An asterisk (*) indicates significantly lower ROS levels than TRV2, $P<0.001$. Abbreviations: ALDH: aldehyde dehydrogenase, HCBT: anthranilate $N$-hydroxycinnamoyl/ benzoyltrasferase. 
putative roles is shown in Figure 6. PTI likely involves a series of interdependent responses and it is perhaps not surprising that there are so many steps at which this immune response can be attenuated. Early signaling events that involve PRR, kinase cascades, and transcription factors are activated upon perception of PAMPs (Asai et al. 2002). Some of these early responses may be PAMP specific and the reliance of our screen on live bacteria (a source of diverse PAMPs) may explain why we did not identify genes involved in these initial PTI events. However, we did identify genes potentially involved in several PTI responses, including the production of ROS and antimicrobial compounds, protein stabilization and degradation, cell wall lignification, and hormone signaling. Understanding the role of each of the 14 candidate genes in PTI will require much further study. However, previous data available for some of the genes or gene classes is discussed below and may provides important starting points for future work.

One of the genes from our screen, cathepsin $B$, has been shown previously to play a role in plant-programmed cell death (PCD) (Gilroy et al. 2007). The HR to P. syringae pv. tomato DC3000 in leaves of $N$. benthamiana was compromised in plants silenced for cathepsin B (Gilroy et al. 2007), similar to what we observed when using a DC3000 inoculum level of $3 \times 10^{6} \mathrm{CFU} / \mathrm{ml}$ (data not shown). In addition, cathepsin $B$ was also involved in controlling the progression of senescence, another form of PCD. Furthermore, an Arabidopsis plant carrying mutations in all three of the cathepsin $B$ orthologs was more susceptible to virulent $P$. syringae pv. tomato DC3000 infection (McLellan et al. 2009). The role of cathepsin B in both PTI and ETI supports the occurrence of shared components in these two immune responses and we plan to use each of the 14 genes identified in this study to further examine that issue in the future.

EDS1 is another gene obtained from the screen for which previous evidence for a role in defense signaling exists. EDS1 is required for SA accumulation and the function of many re-

Table 4. Extent of cell death caused by inoculation of different challengers in plants silenced for the candidate genes from the virus-induced gene silencing library

\begin{tabular}{|c|c|c|c|}
\hline \multirow[b]{2}{*}{ Gene silenced $^{\mathrm{a}}$} & \multicolumn{3}{|c|}{ Extent of cell death } \\
\hline & Full & Partial & None \\
\hline \multicolumn{4}{|l|}{ DC3000 } \\
\hline$T R V 2$ & 8 & 3 & 1 \\
\hline$B A K 1$ & 1 & 3 & 4 \\
\hline$F L S 2$ & 8 & 3 & 1 \\
\hline Aldehyde dehydrogenase & 7 & 3 & 2 \\
\hline Cathepsin B & 5 & 4 & 3 \\
\hline Cyclophilin & 4 & 5 & 3 \\
\hline Cytochrome C & 6 & 4 & 2 \\
\hline Drm-3 & 7 & 2 & 3 \\
\hline$H C B T$ & 2 & 5 & 5 \\
\hline Plastocyanin & 4 & 6 & 2 \\
\hline \multicolumn{4}{|l|}{ DC3000 $\Delta$ hopQ1-1 } \\
\hline$T R V 2$ & 2 & 1 & 5 \\
\hline$B A K 1 *$ & 4 & 4 & 0 \\
\hline$F L S 2$ & 2 & 1 & 5 \\
\hline Aldehyde dehydrogenase & 3 & 2 & 3 \\
\hline Cathepsin B & 2 & 3 & 3 \\
\hline Cyclophilin & 2 & 4 & 1 \\
\hline Cytochrome C & 2 & 2 & 4 \\
\hline Drm-3 & 0 & 2 & 6 \\
\hline$H C B T$ & 0 & 4 & 4 \\
\hline Plastocyanin & 2 & 2 & 4 \\
\hline
\end{tabular}

${ }^{a}$ Inoculation with Pseudomonas syringae pv. tomato DC3000 (approximately $\left.6 \times 10^{6} \mathrm{CFU} / \mathrm{ml}\right)$ or $P$. syringae pv. tomato DC3000 $\Delta$ hopQ1-1 (approximately $3 \times 10^{5} \mathrm{CFU} / \mathrm{ml}$ ). HCBT = anthranilate N-hydroxycinnamoyl/benzoyltransferase. An asterisk (*) indicates significantly faster cell death than the control (Fisher's exact test, $\alpha=0.05$ ). sistance genes in restricting pathogen growth during ETI (Wiermer et al. 2005). SA has been shown to be important for the response against PAMPs from Phytophthora spp. and bacterial flg22 (Tsuda et al. 2008; Halim et al. 2009). Therefore, it is possible that EDS1 functions in both ETI and PTI by its effect on SA accumulation.

Cyclophilins have peptidyl prolyl isomerase activity that facilitates protein folding. An Arabidopsis cyclophilin was previously shown to be involved in the activation of the type III effector AvrRpt2, which was required for its virulence functions and for its recognition by the plant immune system (Coaker et al. 2005). It is tempting to speculate that the cyclophilin we identified here could modulate the stability of PRR, as has been shown for ER-QC components associated with EFR (Li et al. 2009), or other host proteins involved in PTI signaling.

HCBT catalyzes the first committed step in phytoalexin biosynthesis (Yang et al. 1997). Phytoalexins have long been implicated in the defense response against bacterial and fungal pathogens (Thomma et al. 1999; Qiu et al. 2008). It has also been shown that PGN induces the production of the phytoalexin camalexin in Arabidopsis (Gust et al. 2007). Therefore, it is conceivable that HCBT can function in PTI via its role in phytoalexin biosynthesis.

Drm3 shows similarity to a pea gene whose expression is downregulated by auxin and associated with dormancy (Stafstrom et al. 1998). It is known that auxin and SA signaling pathways act antagonistically during the host response to pathogens, with the former promoting disease susceptibility and the latter increasing disease resistance (Wang et al. 2007). Flg22-induced signaling is known to repress the transcription of auxin receptor genes through an RNAi mechanism leading to an increase in resistance (Navarro et al. 2006). The repression of a Drm3 homolog by auxin and our observation here of a loss-of-function phenotype associated with this gene may indicate that Drm3 acts as a positive regulator of PTI that is derepressed when the auxin response is inhibited during PTI.

Ubiquitination is increasingly being found to contribute to PTI and our identification of two genes involved in this process, a putative proteasome $26 \mathrm{~S}$ subunit homolog and a ubiquitin activating enzyme, provides further support for a role of this post-translational modification in plant immunity (Craig et al. 2009). The expression of several genes involved in protein degradation was induced upon flg22 treatment in Arabidopsis (Navarro et al. 2004). An E3 ligase U-box triple mutant in Arabidopsis displayed derepression of PAMP responses and

Table 5. Percentage of plants in which pathogen-associated molecular pattern-triggered immunity (PTI) was compromised when candidate genes from the virus-induced gene silencing library were silenced and evaluated in the cell-death-based assay using $50 \mu \mathrm{M}$ flg22 as the inducer and Pseudomonas syringae pv. tomato DC3000 as the challenger ${ }^{\mathrm{a}}$

\begin{tabular}{lc}
\hline Gene silenced & Plants with PTI compromised (\%) \\
\hline TRV2 & 0 \\
BAK1 & $\mathbf{7 0}$ \\
FLS2 & $\mathbf{7 5}$ \\
Aldehyde dehydrogenase & $\mathbf{2 7}$ \\
Cathepsin B & 6 \\
Cyclophilin & $\mathbf{3 0}$ \\
Cytochrome C & 7 \\
Drm-3 & 15 \\
HCBT & $\mathbf{3 5}$ \\
Plastocyanin & 19 \\
\hline
\end{tabular}

${ }^{a}$ A minimum of 15 plants were evaluated for each assay. Percentages in bold represent those instances in which PTI was compromised as determined by pairwise comparisons of the TRV 2 control with each of the candidate genes with a Fisher's exact test $(\alpha=0.05) . H C B T=$ anthranilate N-hydroxycinnamoyl/benzoyltransferase. 
higher resistance to bacterial and oomycete pathogens, suggesting negative regulation of PTI by E3 ubiquitin ligases (Trujillo et al. 2008). The loss-of-function phenotype we observed here suggests that some ubiquitination components play an important role as positive regulators of PTI.

The combination of VIGS and a cell-death-based assay proved to be a highly effective approach to screen a large number of genes for possible involvement in PTI. Other experimental approaches to identify PTI-associated genes have been reported previously. These methods typically have employed purified PAMPs and measure early events such as the oxidative burst, alkalinization of cell culture medium, gene induction, and MAPK activation, and later responses such as callose deposition at the cell wall and inhibition of seedling growth (Boller and Felix 2009). Some of these methods are not amenable to a high-throughput screen, or are specific to a certain PTI pathway, whereas others measure responses that occur within minutes of microbial recognition and may not uncover important downstream events.

The cell-death-based assay we used is based on earlier work by Klement and associates (2003) which was further optimized by $\mathrm{Oh}$ and Collmer (2005). It relies on nonpathogenic bacteria as a source of PAMPs and various challengers that cause either disease- or immunity-associated cell death. Therefore, the genes identified by this approach may play a role in responsiveness to a wide array of different PAMPs.

Data from our experiments on ROS production and using flg22 as the inducer in the cell death assay also support the hypothesis that some of the genes identified are not exclusively regulated by the FLS2 pathway but may be acting downstream of other PRR (Fig. 5; Table 5). There is previous evidence that subtle differences exist in plant responses to different PAMPs. For example, defense gene $P R-1$ expression, transcriptional changes, and phytoalexin production were differently induced by flg22, chitin, and PGN, respectively, in Arabidopsis (Gust et al. 2007).

An advantage of the combined cell death assays-VIGS approach is that it can be easily modified to target specific PTI pathways and to increase the efficiency of gene identification. For example, individual PAMPs such as PGN, EF-Tu, lipopolysaccharide (LPS), and others could be used as the inducer of PTI to identify host genes involved in recognition of these molecules. In addition, as the percentage of candidates identified from our $P$. syringae-induced genes was approximately 20-fold higher than that identified from the general library screen $(5.1$ versus $0.23 \%$ ), it may be worthwhile to conduct preliminary transcriptional profiling with the specific PAMPs of interest in order to enrich for relevant PTI-associated genes.

It is important to note that we still have a poor understanding of why bacteria fail to grow in leaf tissue protected by PTI. Our data suggest that the barriers against bacterial growth are highly multifactorial and that compromising a single downstream component of PTI is insufficient to permit or enhance substantial bacterial growth. Our screen for cell death following bacterial challenge involved relatively high levels of inoculum. Thus, to reveal a VIGS-induced defect in PTI, the bacteria primarily had to succeed in deploying the type III secretion system (T3SS) and deliver functional effectors. The notion that PTI-protected tissue does not support delivery of effectors by challenge bacteria is supported by a concurrent study documenting the failure of $P$. syringae pv. tomato DC3000 to deliver into such tissue the AvrPto-Cya translocation reporter, which can be assayed for adenylate cyclase activity in plant cells rather than elicitation of cell death (Oh et al. 2010). However, the mechanism for this inhibition has not been determined, and it could be a secondary consequence of antibacterial stresses in PTI-protected tissue. The genes found in this screen may be useful in future work in understanding how PTI impacts T3SS function as well as inhibiting general bacterial growth.

We identified 14 genes from a screen of $>3,200$ and it can be asked whether this is a reasonable number to expect from a screen such as this. It is important to point out certain aspects of our screen that may have affected the number of genes identified. First, the library we used was derived from leaf tissues exposed to a variety of elicitors and not specifically to PAMPs. It is possible that PAMP treatment would have enriched the library more for PTI-associated genes (note that our screen of 133 immunity-associated genes likely was enriched for genes involved in PTI). Second, we initially silenced one plant per gene and discovered only later that, because of the experimental variability of the assay, silencing of three plants with each gene gave a higher likelihood of observing PTI breakdown. Third, we required that silencing of a gene had to compromise PTI in at least three independent experiments to be considered further. This cut-off excluded some genes that may, in fact, have a more subtle effect on PTI. Finally, it is important to consider that we screened only 3,200 gene fragments (and not all of these were unique). The total number of genes expressed in $N$. benthamiana leaves is unknown but, based on tomato, another solanaceous species, is estimated to be approximately 16,500 (L. Mueller, personal communication). Hence, our screen was not a saturating one and it is possible that additional genes involved in PTI could be identified by this method.

Suboptimal efficiency of gene silencing is another factor that may have prevented us from obtaining a larger number of genes from the screen, and stronger phenotypes in our followup assays. Although the degree of silencing achieved for the genes analyzed was good, we did not obtain complete silencing of the genes; this is to be expected because we used VIGS and not gene-knockout backgrounds. We also found that the silencing constructs for 2 of the 14 genes, cyclophilin and EDS1, might knock down expression of related, off-target genes (Supplementary Table S4). We performed RT-PCR for a predicted off-target of cyclophilin, which we call cyclophilin homolog TC9299, and found that the transcript abundance of this gene was, indeed, reduced in silenced plants. TC9299 also encodes a cyclophilin and, therefore, the observed phenotypes with the cyclophilin construct could be due to the combined silencing of both of these genes.

We observed that silencing of 4 of the 14 PTI-associated genes also caused defects in plant growth or development. These results add to several previous observations that disruption of a gene involved in immunity also affects plant morphology. For example, the RLK ERECTA that is involved in plant development and the COPINE1/BONZAI1 genes from Arabidopsis were shown to have roles in immunity to bacterial, fungal, and oomycete pathogens, and plants with mutations in these genes have developmental defects (Godiard et al. 2003; Yang et al. 2006; Sanchez-Rodriguez et al. 2009). Similarly, BAK1 is now known to play a role in both a hormone-sensitive developmental pathway and in PTI (Kinoshita et al. 2005; Chinchilla et al. 2007). In our case, silencing of four genes caused stunting of $N$. benthamiana and, in one case, leaf chlorosis. It is interesting that similar observations have been made in genus Drosophila, in which the well-characterized Toll receptor plays a role in embryo development and in immunity, and a recent screen revealed that RNAi silencing of some genes in the immune-deficiency (Imd) pathway caused developmental defects (Foley and O'Farrell 2004). Together, these examples suggest that eukaryotes have relied on certain conserved genes to evolve mechanisms related to both growth and development and immune responses.

RNAi screens also have been performed successfully in other eukaryotes to identify regulators of the innate immune response. Genes involved in signaling, proteolysis, intracellular protein 
transport, protein synthesis, transcriptional regulation, and defense responses have been identified to be positive regulators of immunity in diverse species such as members of genus Drosophila, Caenorhabditis elegans, and the mouse (Foley and O'Farrell 2004; Alper et al. 2008; Cronin et al. 2009). Silencing of 10,689 genes in Drosophila spp. identified $790(7.4 \%)$ that may play a role in resistance to Serratia marcescens, while another study that silenced 7,216 genes in genus Drosophila identified $49(0.68 \%)$ to be involved in the LPS-induced Imd signaling pathway (Alper et al. 2008; Cronin et al. 2009).

It is not surprising that a large number of plant genes are involved in PTI, considering the diversity of pathogenic and nonpathogenic microbes that plants encounter. Moreover, the large number of pathogen effectors that have evolved to undermine PTI points to a corresponding complexity of plant immune processes (Lewis et al. 2009). For example, AvrPto, AvrPtoB, HopM1, HopAI1, and HopU1 are bacterial effectors that have been found to interfere with either the formation of PRR complexes, MAPK cascades, callose deposition, secretory vesicle pathways, DNA or RNA processing, or the chloroplast during pathogenesis (Boller and $\mathrm{He}$ 2009; Guo et al. 2009; Lewis et al. 2009). The genes we identified here highlight the potential importance of protein stability, secondary metabolism, and hormone signaling in PTI and raise the possibility that each of these processes is targeted by pathogen effectors. In the future, it will be interesting to investigate which of these processes may be targeted by pathogen effectors and the underlying mechanisms involved. Such knowledge of the molecular basis of PTI may ultimately lead to manipulation of this important host response in order to develop crop plants with more durable resistance to pathogens.

\section{MATERIALS AND METHODS}

Bacterial strains.

Bacterial strains used in this study are listed in Supplementary Table S5. Pseudomonas strains were grown in King's B (KB) medium at $30^{\circ} \mathrm{C}$. A. tumefaciens and Escherichia coli strains were grown in Luria-Bertani medium at 30 and $37^{\circ} \mathrm{C}$, respectively. Antibiotics were used at the following concentrations: ampicillin $(100 \mu \mathrm{g} / \mathrm{ml})$, kanamycin $(50 \mu \mathrm{g} / \mathrm{ml})$, rifampicin $(10 \mu \mathrm{g} / \mathrm{ml})$, and spectinomycin $(50 \mu \mathrm{g} / \mathrm{ml})$.

VIGS.

VIGS was performed as described earlier (Velásquez et al. 2009). All $N$. benthamiana plants were kept in a growth chamber with a 16-h day length, a temperature of 20 to $22^{\circ} \mathrm{C}$, and $50 \%$ relative humidity $(\mathrm{RH})$ for at least three and a half weeks before they were used for the assays.

\section{PTI assay.}

The PTI cell death assay was performed as described (Chakravarthy et al. 2009). The inducers were $P$. fluorescens 55 at $10^{9} \mathrm{CFU} / \mathrm{ml}$, $P$. putida $\mathrm{KT} 2240$ at $10^{8} \mathrm{CFU} / \mathrm{ml}$, and $A$. tumefaciens GV2260 at $5 \times 10^{8} \mathrm{CFU} / \mathrm{ml}$. The challengers were P. syringae pv. tomato $\mathrm{DC} 3000$ at $2 \times 10^{7} \mathrm{CFU} / \mathrm{ml}$, P. syringae

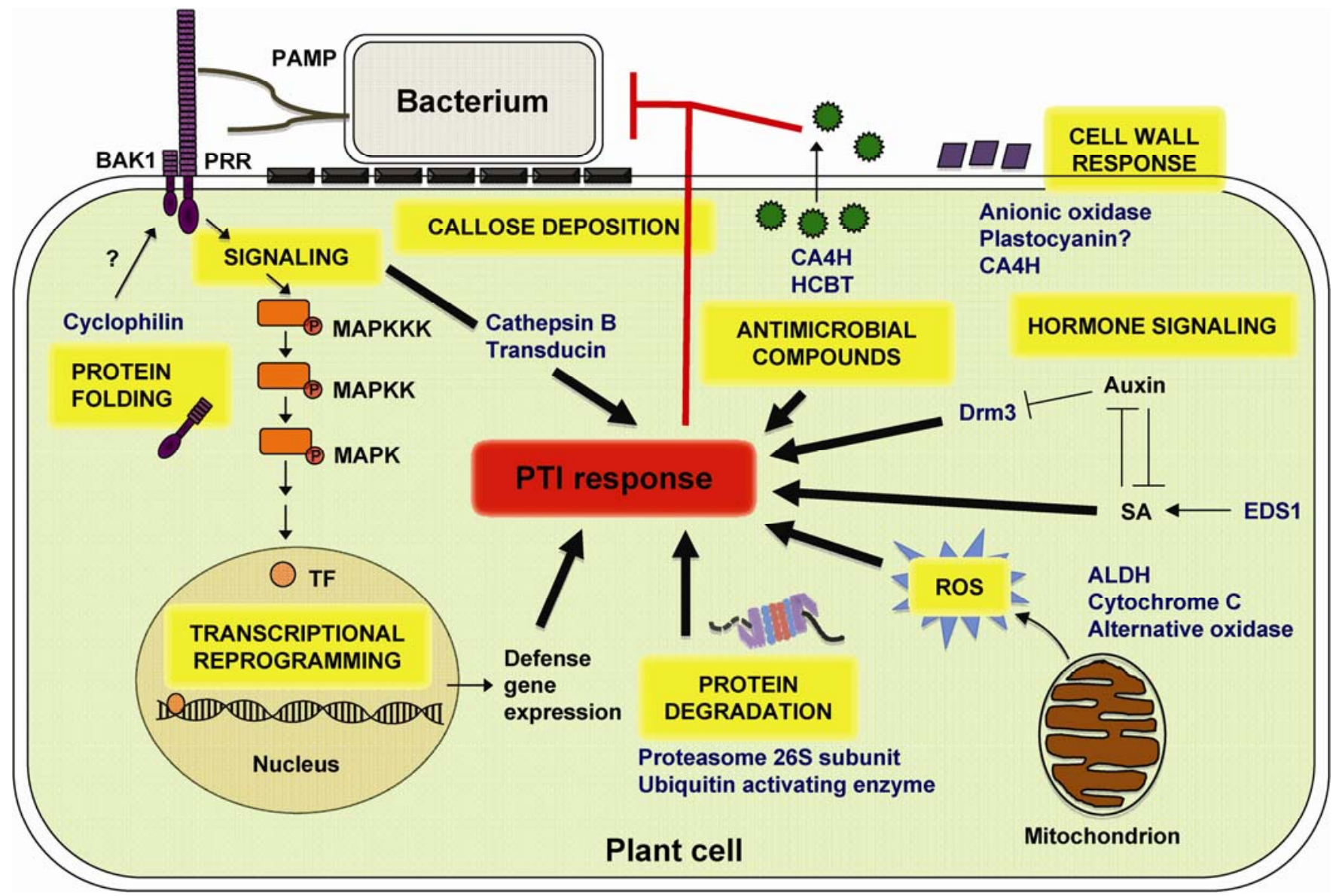

Fig. 6. Model summarizing the possible roles of the genes identified in pathogen-associated molecular pattern (PAMP)-triggered immunity. The model depicts some of the major cellular processes that are known to be involved upon PAMP perception (yellow boxes) and the genes identified in this study (blue). Note that $\mathrm{CA} 4 \mathrm{H}$ may play a role in the production of antimicrobial compounds during secondary metabolism as well as in lignin biosynthesis, which is part of the cell wall response. Abbreviations: ALDH: aldehyde dehydrogenase, CA4H: cinnamic acid 4-hydroxylase, HCBT: anthranilate $N$-hydroxycinnamoyl/benzoyltransferase, SA: salicylic acid, and TF: transcription factor. 
pv. tomato DC3000 $\Delta$ hopQ1-1 at $1 \times 10^{6} \mathrm{CFU} / \mathrm{ml}$, and $P$. syringae pv. tabaci 11528 at $1 \times 10^{6} \mathrm{CFU} / \mathrm{ml}$. The time between induction and challenge was $7 \mathrm{~h}$.

Appearance of cell death in the overlapping area in which the inducer and challenger were infiltrated indicated that PTI was compromised. Cell death due to ETI started 2 days after infiltration while that caused by disease appeared by day 4 . Evaluation of plants was terminated when the TRV2 control plants started to show cell death in the overlapping area. A Fisher's exact test $(\alpha=0.05)$ was used to establish whether the number of times in which PTI was compromised was significantly different for a particular gene compared with the TRV2 control. This test is used to determine whether there are nonrandom associations between two categorical variables (i.e., if silencing had any effect on the observed breakdown of PTI).

\section{PTI assay using flg22 as an inducer.}

The same procedure as that described for the cell-deathbased assay was employed, except that $50 \mu \mathrm{M}$ flg22 (GenScript, Piscataway NJ, U.S.A.) and $P$. syringae pv. tomato DC3000 at $1 \times 10^{7} \mathrm{CFU} / \mathrm{ml}$ were used as the inducer and challenger, respectively.

\section{Evaluation of cell death progression due to challenger inoculation.}

To prepare the inoculum, $P$. syringae pv. tomato DC3000 and DC3000 $\triangle h o p Q 1-1$ were streaked on KB plates with the appropriate antibiotics and grown overnight at $30^{\circ} \mathrm{C}$. The next day, bacteria were spread with $150 \mu \mathrm{l}$ of sterile liquid $\mathrm{KB}$ and grown for an additional day. Cells were then resuspended in 10 $\mathrm{mM} \mathrm{MgCl} 2$ to the desired optical density at $600 \mathrm{~nm}$. The inocula used were $3 \times 10^{6}, 6 \times 10^{6}$, and $2 \times 10^{7} \mathrm{CFU} / \mathrm{ml}$ for DC3000 and $1 \times 10^{5}, 3 \times 10^{5}$, and $1 \times 10^{6} \mathrm{CFU} / \mathrm{ml}$ for $\triangle$ hopQ1-1. Data obtained for one titer each of DC3000 and DC3000 $\Delta$ hopQ1-1 are shown in Table 4, whereas the other data obtained are not shown.

Seven-week-old $N$. benthamiana plants silenced for the candidate genes were inoculated with DC3000 and $\Delta$ hopQ1-1 using a blunt syringe. Plants were kept in a room with continuous light, 22 to $24^{\circ} \mathrm{C}$ temperature, and $30 \% \mathrm{RH}$. The extent of cell death was scored as full $(>75 \%$ of the infiltrated area showed necrosis), partial (10-75\%), or none ( $<10 \%$ cell death). Plants were evaluated until there was $100 \%$ cell death in all the spots for a particular inoculum level.

\section{Measurement of ROS production.}

Approximately 20 days after VIGS was initiated, silenced plants were assayed for ROS production. Discs from young leaves were punched out with a 4-mm-diameter cork borer. Leaf disks were floated adaxial side up in a 96-well black plate (Nunc, Roskilde, Denmark) containing $200 \mu \mathrm{l}$ of water per well, and left at room temperature overnight. The next day, the water was removed, and $100 \mu \mathrm{l}$ of a solution containing the following was added: $100 \mathrm{nM}$ flg22 (GenScript), luminol at 34 $\mu \mathrm{g} / \mathrm{ml}$ (Sigma-Aldrich, St. Louis), and horseradish peroxidase at $20 \mu \mathrm{g} / \mathrm{ml}$ (type VI-A; Sigma-Aldrich) in water. Luminescence was measured using the GENios Pro plate reader (Tecan, San Jose, CA, U.S.A.) and analyzed using Magellan software (Tecan). Three leaf disks per plant were taken, and at least three plants silenced for each gene were considered in each experiment. Controls lacking flg22 were included for each plant.

\section{RNA extraction and cDNA synthesis.}

RNA was isolated from leaf tissue following the Concert plant RNA reagent method from Invitrogen (Carlsbad, CA, U.S.A.). Genomic DNA contamination was removed with RQ1 RNasefree DNase from Promega Corp. (Madison, WI, U.S.A.) and the
RNA purified using the RNeasy mini kit from Qiagen (Valencia, CA, U.S.A.). DNase-treated RNA $(1 \mu \mathrm{g})$ was used for firststrand cDNA synthesis with $0.5 \mu \mathrm{g}$ of oligo $(\mathrm{dT})_{12-18}$ primer and $200 \mathrm{U}$ of Superscript III reverse transcriptase from Invitrogen in a $20-\mu 1$ reaction. A negative control without the reverse transcriptase enzyme was included for each RNA sample to verify the absence of contaminating genomic DNA.

\section{RT-PCR to analyze gene expression.}

Tissue was harvested from wild-type $N$. benthamiana plants inoculated with either a suspension of $P$. fluorescens at $1 \times 10^{9}$ $\mathrm{CFU} / \mathrm{ml}$ or $10 \mathrm{mM} \mathrm{MgCl}_{2}$. The $P$. fluorescens inoculum was prepared as described for the cell-death-based assay. Samples were taken at 6,12 , and $24 \mathrm{~h}$ after infiltration.

RT-PCR was performed in a $25-\mu$ l reaction volume with $1 \mu \mathrm{l}$ of cDNA, $0.2 \mu \mathrm{M}$ each primer, $0.2 \mathrm{mM}$ each dNTP, and 0.625 U of Fisher Scientific Taq polymerase (Fair Lawn, NJ, U.S.A.). PCR amplicons were run on a $1.5 \%$ agarose gel, stained with ethidium bromide, and visualized using the Gel Doc XR from Bio-Rad Laboratories (Hercules, CA, U.S.A.). RT-PCR of elongation factor $1 \alpha$ was used as a loading control.

FLS2 primers used to evaluate gene induction were the same as reported by Hann and Rathjen (2007); the plastocyanin primers were designed using the VIGS construct sequence (Supplementary Table S6).

\section{ACKNOWLEDGMENTS}

We thank past and current members of the Martin lab and H.-S. Oh for their help with assay infiltrations during the initial phase of the VIGS screen; E. Pasoreck, S. Cohen, J. Gu, B. Randall, D. Opel, and D. Dunham for technical assistance; S. Cunnac and J. Munkvold for critical comments on the manuscript; and S. Despa, Statistical Consulting Unit, Cornell University, and C.-S. Oh, and J. Munkvold for help in statistical analysis of the data. Funding for this work was from National Science Foundation grant no. DBI-0605059 (to A. Collmer and G. B. Martin).

\section{LITERATURE CITED}

Alper, S., Laws, R., Lackford, B., Boyd, W. A., Dunlap, P., Freedman, J. H., and Schwartz, D. A. 2008. Identification of innate immunity genes and pathways using a comparative genomics approach. Proc. Natl. Acad. Sci. U.S.A. 105:7016-7021.

Asai, T., Tena, G., Plotnikova, J., Willmann, M. R., Chiu, W. L., GomezGomez, L., Boller, T., Ausubel, F. M., and Sheen, J. 2002. MAP kinase signalling cascade in Arabidopsis innate immunity. Nature 415:977-983.

Bent, A. F., and Mackey, D. 2007. Elicitors, effectors, and $R$ genes: The new paradigm and a lifetime supply of questions. Annu Rev Phytopathol 45:399-436.

Boller, T., and Felix, G. 2009. A renaissance of elicitors: Perception of microbe-associated molecular patterns and danger signals by patternrecognition receptors. Annu. Rev. Plant Biol. 60:379-406.

Boller, T., and He, S. Y. 2009. Innate immunity in plants: An arms race between pattern recognition receptors in plants and effectors in microbial pathogens. Science 324:742-744.

Chakravarthy, S., Velásquez, A. C., and Martin, G. B. 2009. Assay for pathogen-associated molecular pattern (PAMP)-triggered immunity (PTI) in plants. J. Vis. Exp. 31 DOI:10.3791/1442

Chinchilla, D., Bauer, Z., Regenass, M., Boller, T., and Felix, G. 2006. The Arabidopsis receptor kinase FLS2 binds flg22 and determines the specificity of flagellin perception. Plant Cell 18:465-476.

Chinchilla, D., Zipfel, C., Robatzek, S., Kemmerling, B., Nurnberger, T., Jones, J. D., Felix, G., and Boller, T. 2007. A flagellin-induced complex of the receptor FLS2 and BAK1 initiates plant defence. Nature 448:497-500.

Coaker, G., Falick, A., and Staskawicz, B. 2005. Activation of a phytopathogenic bacterial effector protein by a eukaryotic cyclophilin. Science 308:548-550.

Craig, A., Ewan, R., Mesmar, J., Gudipati, V., and Sadanandom, A. 2009. E3 ubiquitin ligases and plant innate immunity. J. Exp. Bot. 60:1123-1132.

Cronin, S. J., Nehme, N. T., Limmer, S., Liegeois, S., Pospisilik, J. A., Schramek, D., Leibbrandt, A., Simoes Rde, M., Gruber, S., Puc, U., Ebersberger, I., Zoranovic, T., Neely, G. G., von Haeseler, A., Ferrandon, 
D., and Penninger, J. M. 2009. Genome-wide RNAi screen identifies genes involved in intestinal pathogenic bacterial infection. Science 325:340-343.

del Pozo, O., Pedley, K. F., and Martin, G. B. 2004. MAPKKKalpha is a positive regulator of cell death associated with both plant immunity and disease. EMBO (Eur. Mol. Biol. Organ.) J. 23:3072-3082.

Foley, E., and O'Farrell, P. H. 2004. Functional dissection of an innate immune response by a genome-wide RNAi screen. PLoS Biol. 2:e203.

Gilroy, E. M., Hein, I., van der Hoorn, R., Boevink, P.C., Venter, E., McLellan, H., Kaffarnik, F., Hrubikova, K., Shaw, J., Holeva, M., Lopez, E. C., Borras-Hidalgo, O., Pritchard, L., Loake, G. J., Lacomme, C., and Birch, P. R. 2007. Involvement of cathepsin $B$ in the plant disease resistance hypersensitive response. Plant J. 52:1-13.

Gimenez-Ibanez, S., Hann, D. R., Ntoukakis, V., Petutschnig, E., Lipka, V., and Rathjen, J. P. 2009. AvrPtoB targets the LysM receptor kinase CERK1 to promote bacterial virulence on plants. Curr. Biol. 19:423-429.

Godiard, L., Sauviac, L., Torii, K. U., Grenon, O., Mangin, B., Grimsley, N. H., and Marco, Y. 2003. ERECTA, an LRR receptor-like kinase protein controlling development pleiotropically affects resistance to bacterial wilt. Plant J. 36:353-365.

Goodin, M. M., Zaitlin, D., Naidu, R. A., and Lommel, S. A. 2008. Nicotiana benthamiana: Its history and future as a model for plant-pathogen interactions. Mol. Plant-Microbe Interact. 21:1015-1026.

Guo, M., Tian, F., Wamboldt, Y., and Alfano, J. R. 2009. The majority of the type III effector inventory of Pseudomonas syringae pv. tomato DC3000 can suppress plant immunity. Mol. Plant-Microbe Interact. 22:1069-1080.

Gust, A. A., Biswas, R., Lenz, H. D., Rauhut, T., Ranf, S., Kemmerling, B., Gotz, F., Glawischnig, E., Lee, J., Felix, G., and Nurnberger, T. 2007. Bacteria-derived peptidoglycans constitute pathogen-associated molecular patterns triggering innate immunity in Arabidopsis. J. Biol. Chem. 282:32338-32348.

Halim, V. A., Altmann, S., Ellinger, D., Eschen-Lippold, L., Miersch, O., Scheel, D., and Rosahl, S. 2009. PAMP-induced defense responses in potato require both salicylic acid and jasmonic acid. Plant J. 57:230-242.

Hann, D. R., and Rathjen, J. P. 2007. Early events in the pathogenicity of Pseudomonas syringae on Nicotiana benthamiana. Plant J. 49:607-618.

Heese, A., Hann, D. R., Gimenez-Ibanez, S., Jones, A. M., He, K., Li, J., Schroeder, J. I., Peck, S. C., and Rathjen, J. P. 2007. The receptor-like kinase SERK3/BAK1 is a central regulator of innate immunity in plants. Proc. Natl. Acad. Sci. U.S.A. 104:12217-12222.

Kinoshita, T., Cano-Delgado, A., Seto, H., Hiranuma, S., Fujioka, S., Yoshida, S., and Chory, J. 2005. Binding of brassinosteroids to the extracellular domain of plant receptor kinase BRI1. Nature 433:167-171.

Klement, Z., Bozso, Z., Kecskes, M. L., Besenyei, E., Arnold, C., and Ott, P. G. 2003. Local early induced resistance of plants as the first line of defence against bacteria. Pest Manage. Sci .59:465-474.

Kvitko, B. H., Park, D. H., Velásquez, A. C., Wei, C. F., Russell, A. B., Martin, G. B., Schneider, D. J., and Collmer, A. 2009. Deletions in the repertoire of Pseudomonas syringae pv. tomato DC3000 type III secretion effector genes reveal functional overlap among effectors. PLoS Pathog. 5:e1000388.

Lewis, J. D., Guttman, D. S., and Desveaux, D. 2009. The targeting of plant cellular systems by injected type III effector proteins. Semin. Cell Dev. Biol. 20:1055-1063.

Li, J., Zhao-Hui, C., Batoux, M., Nekrasov, V., Roux, M., Chinchilla, D., Zipfel, C., and Jones, J. D. 2009. Specific ER quality control components required for biogenesis of the plant innate immune receptor EFR. Proc. Natl. Acad. Sci. U.S.A. 106:15973-15978.

Lu, R., Malcuit, I., Moffett, P., Ruiz, M. T., Peart, J., Wu, A. J., Rathjen, J. P., Bendahmane, A., Day, L., and Baulcombe, D. C. 2003. High throughput virus-induced gene silencing implicates heat shock protein 90 in plant disease resistance. EMBO (Eur. Mol. Biol. Organ.) J. 22:5690-5699.

McLellan, H., Gilroy, E. M., Yun, B. W., Birch, P. R., and Loake, G. J. 2009. Functional redundancy in the Arabidopsis cathepsin B gene family contributes to basal defence, the hypersensitive response and senescence. New Phytol. 183:315-326.

Miya, A., Albert, P., Shinya, T., Desaki, Y., Ichimura, K., Shirasu, K., Narusaka, Y., Kawakami, N., Kaku, H., and Shibuya, N. 2007. CERK1, a LysM receptor kinase, is essential for chitin elicitor signaling in Arabidopsis. Proc. Natl. Acad. Sci. U.S.A. 104:19613-19618.

Mysore, K. S., Crasta, O. R., Tuori, R. P., Folkerts, O., Swirsky, P. B., and Martin, G. B. 2002. Comprehensive transcript profiling of Pto- and Prfmediated host defense responses to infection by Pseudomonas syringae pv. tomato. Plant J. 32:299-315.

Navarro, L., Zipfel, C., Rowland, O., Keller, I., Robatzek, S., Boller, T., and Jones, J. D. 2004. The transcriptional innate immune response to flg22. Interplay and overlap with Avr gene-dependent defense responses and bacterial pathogenesis. Plant Physiol. 135:1113-1128.

Navarro, L., Dunoyer, P., Jay, F., Arnold, B., Dharmasiri, N., Estelle, M., Voinnet, O., and Jones, J. D. 2006. A plant miRNA contributes to antibacterial resistance by repressing auxin signaling. Science 312:436-439.

Oh, H. S., and Collmer, A. 2005. Basal resistance against bacteria in Nicotiana benthamiana leaves is accompanied by reduced vascular staining and suppressed by multiple Pseudomonas syringae type III secretion system effector proteins. Plant J. 44:348-359.

Oh, H. S., Park, D. H., and Collmer, A. C. 2010. Components of the Pseudomonas syringae type III secretion system can suppress and may elicit plant innate immunity. Mol. Plant-Microbe Interact. 23:727-739.

Peart, J. R., Mestre, P., Lu, R., Malcuit, I., and Baulcombe, D. C. 2005. NRG1, a CC-NB-LRR protein, together with N, a TIR-NB-LRR protein, mediates resistance against tobacco mosaic virus. Curr. Biol. 15:968-973.

Qiu, J. L., Fiil, B. K., Petersen, K., Nielsen, H. B., Botanga, C. J., Thorgrimsen, S., Palma, K., Suarez-Rodriguez, M. C., SandbechClausen, S., Lichota, J., Brodersen, P., Grasser, K. D., Mattsson, O., Glazebrook, J., Mundy, J., and Petersen, M. 2008. Arabidopsis MAP kinase 4 regulates gene expression through transcription factor release in the nucleus. EMBO (Eur. Mol. Biol. Organ.) J. 27:2214-2221.

Ron, M., and Avni, A. 2004. The receptor for the fungal elicitor ethyleneinducing xylanase is a member of a resistance-like gene family in tomato. Plant Cell 16:1604-1615

Saijo, Y., Tintor, N., Lu, X., Rauf, P., Pajerowska-Mukhtar, K., Haweker, H., Dong, X., Robatzek, S., and Schulze-Lefert, P. 2009. Receptor quality control in the endoplasmic reticulum for plant innate immunity. EMBO (Eur. Mol. Biol. Organ.) J.. 28:3439-3449.

Sanchez-Rodriguez, C., Estevez, J. M., Llorente, F., Hernandez-Blanco, C., Jorda, L., Pagan, I., Berrocal, M., Marco, Y., Somerville, S., and Molina, A. 2009. The ERECTA receptor-like kinase regulates cell wallmediated resistance to pathogens in Arabidopsis thaliana. Mol. PlantMicrobe Interact. 22:953-963.

Schwessinger, B., and Zipfel, C. 2008. News from the frontline: Recent insights into PAMP-triggered immunity in plants. Curr. Opin. Plant Biol. 11:389-395.

Stafstrom, J. P., Ripley, B. D., Devitt, M. L., and Drake, B. 1998. Dormancy-associated gene expression in pea axillary buds. Cloning and expression of PsDRM1 and PsDRM2. Planta 205:547-552.

Thilmony, R., Underwood, W., and He, S. Y. 2006. Genome-wide transcriptional analysis of the Arabidopsis thaliana interaction with the plant pathogen Pseudomonas syringae pv. tomato DC3000 and the human pathogen Escherichia coli O157:H7. Plant J. 46:34-53.

Thomma, B. P., Nelissen, I., Eggermont, K., and Broekaert, W. F. 1999. Deficiency in phytoalexin production causes enhanced susceptibility of Arabidopsis thaliana to the fungus Alternaria brassicicola. Plant J. 19:163-171.

Trujillo, M., Ichimura, K., Casais, C., and Shirasu, K. 2008. Negative regulation of PAMP-triggered immunity by an E3 ubiquitin ligase triplet in Arabidopsis. Curr. Biol. 18:1396-1401.

Tsuda, K., Sato, M., Glazebrook, J., Cohen, J. D., and Katagiri, F. 2008. Interplay between MAMP-triggered and SA-mediated defense responses. Plant J. 53:763-775.

Velásquez, A. C., Chakravarthy, S., and Martin, G. B. 2009. Virus-induced gene silencing (VIGS) in Nicotiana benthamiana and tomato. J. Vis. Exp. 28 DOI:10.3791/1292.

Wang, D., Pajerowska-Mukhtar, K., Culler, A. H., and Dong, X. 2007. Salicylic acid inhibits pathogen growth in plants through repression of the auxin signaling pathway. Curr. Biol. 17:1784-1790.

Wiermer, M., Feys, B. J., and Parker, J. E. 2005. Plant immunity: The EDS1 regulatory node. Curr. Opin. Plant Biol. 8:383-389.

Yang, Q., Reinhard, K., Schiltz, E., and Matern, U. 1997. Characterization and heterologous expression of hydroxycinnamoyl/benzoyl-CoA:anthranilate N-hydroxycinnamoyl/benzoyltransferase from elicited cell cultures of carnation, Dianthus caryophyllus L. Plant Mol. Biol. 35:777-789.

Yang, S., Yang, H., Grisafi, P., Sanchatjate, S., Fink, G. R., Sun, Q., and Hua, J. 2006. The BON/CPN gene family represses cell death and promotes cell growth in Arabidopsis. Plant J. 45:166-179.

Zipfel, C. 2009. Early molecular events in PAMP-triggered immunity. Curr. Opin. Plant Biol. 12:414-420.

Zipfel, C., Robatzek, S., Navarro, L., Oakeley, E. J., Jones, J. D., Felix, G., and Boller, T. 2004. Bacterial disease resistance in Arabidopsis through flagellin perception. Nature 428:764-767.

Zipfel, C., Kunze, G., Chinchilla, D., Caniard, A., Jones, J. D., Boller, T. and Felix, G. 2006. Perception of the bacterial PAMP EF-Tu by the receptor EFR restricts Agrobacterium-mediated transformation. Cell $125: 749-760$

An explanatory sentence has been added to the caption for Figure 1. Figure 1B presented two different photographs of the same leaf area to represent different control experiments (i.e., BAK1: P. putida and DC3000 and FLS2: P. fluorescens and DCAhopQ1-1). The authors have closely reexamined all of the original photographs presented in this figure and have verified that the images shown in the revised figure are correct. The file online was changed on May 29, 2015. 